\title{
Recombinant trail: a synergistic effect in myeloid leukemias
}

\author{
Filipa Carvalho ${ }^{1 *}$, A Sofia Coelho², Cátia Domingues², João A Carvalho ${ }^{1}$, André Ribeiro ${ }^{1}$, Rui M Santos ${ }^{1}$, \\ A Cristina Gonçalves ${ }^{1,3}$, Vera Alves ${ }^{1}$, Teresa Silva ${ }^{1}$, Marília Dourado ${ }^{1,3}$, José M Nascimento-Costa ${ }^{1,4,5}$, \\ Ana B Sarmento-Ribeiro 1,3,6
}

From 16th International Charles Heidelberger Symposium on Cancer Research Coimbra, Portugal. 26-28 September 2010

The tumor necrosis factor (TNF)-related apoptosis inducing ligand (TRAIL/Apo-2L) is a member of the TNF superfamily that trigger and activate 2 death receptors, DR4 and DR5, and 2 decoy receptors, DcR1 and DcR2. Several studies demonstrated that TRAIL in monotherapy can induces cancer cell death cells, but few have been done in leukemias in combination with conventional drugs. The aim of this work is to analyse the potential synergist effect of a recombinant TRAIL (rhTRAIL) in myeloid leukemias.

For this, 2 myeloid leukemia cell lines, HL-60 (promyelocitic leukemia) and K-562 (Chronic Myeloid Leukemia) were treated with different concentrations of rhTRAIL as single agent and in combination with ATRA (all-transretinoic acid) and imatinib, respectively. The viability was measure using the trypan blue test and cell death by flow cytometry (FC) and Optical Microscopy. TRAIL and TRAIL-Rs were evaluated by FC.

Our results show that rhTRAIL induced a decrease in cell viability inducing cell death, in a time, dose and cell type dependent manner. We observe an $\mathrm{IC}_{50}$ in HL-60 treated for $48 \mathrm{~h}$ of $250 \mathrm{ng} / \mathrm{mL}$, although in K562 cells, rhTRAIL wasn't able to induce a significant effect. However, when we previously treated the cells with ATRA or IMATINIB a synergistic effect is observed, mainly in HL60 cells. These results may be correlated with the differential TRAIL receptors expression, namely the presence of the anti-apoptotic TRAIL receptors, in K562 cells. On the other hand, the higher percentage of proapoptotic TRAIL receptors may be related with the therapeutic efficacy of rhTRAIL in HL-60 cells. Our study suggests that rhTRAIL can be use as a new therapeutic

\footnotetext{
* Correspondence: filipavcarvalho@gmail.com

${ }^{1}$ Faculty of Medicine, University of Coimbra (FMUC), Coimbra, Portugal

Full list of author information is available at the end of the article
}

aproach in APL, as single agent. However, it can potentiate the cytotoxic effect of conventional drugs.

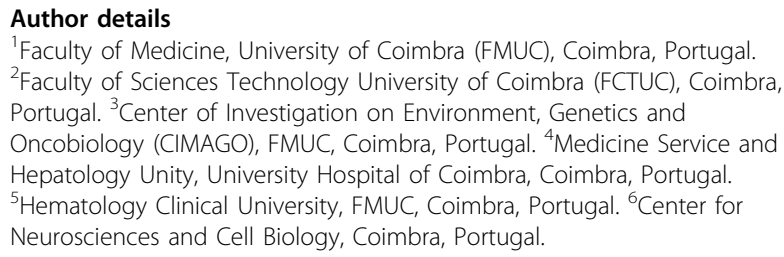

Published: 24 September 2010

\section{doi:}

Cite this article as: Carvalho et al:: Recombinant trail: a synergistic effect in myeloid leukemias. BMC Proceedings 2010 4(Suppl 2):P46.

\section{Submit your next manuscript to BioMed Central and take full advantage of: \\ - Convenient online submission \\ - Thorough peer review \\ - No space constraints or color figure charges \\ - Immediate publication on acceptance \\ - Inclusion in PubMed, CAS, Scopus and Google Scholar \\ - Research which is freely available for redistribution \\ Submit your manuscript at www.biomedcentral.com/submit}

